\title{
User Generated Content Platform as a New Media for Technopreneur Writer in Industrial Age Version 4
}

\author{
Feri Sulianta $^{1} \&$ Prof. Dr. H. Sapriya, M.Ed. ${ }^{2}$ \\ ${ }^{1}$ Widyatama University, Indonesia \\ ${ }^{2}$ Indonesia University of Education, Indonesia \\ Correspondence: Feri Sulianta, Widyatama University, Indonesia. E-mail: feri.sulianta@widyatama.ac.id
}

Received: April 04, 2018

Accepted: September 28, 2018

Online Published: May 10, 2019

doi:10.5430/ijhe.v8n3p63

URL: https://doi.org/10.5430/ijhe.v8n3p63

\begin{abstract}
In today's society, information technology transforms the way people do business and activities. Such phenomenon eliminates the previous jobs and creates a new job title. In this regards, professional writers offer new jobs in this digital age. Books and papers are substituted with new platforms because of industrial changes. Web portals, paperless media, tablets, smartphones and other gadgets were created to spread information. However, these have become tools and media for authors in the 21st century. User generated content platform is the most promising tunnel for technopreneur writer. A lot of features can be used to write and asses the author's materials. For example, analytic dashboard or perception content analysis are powerful tools to asses the effectiveness of author's work. There are certain strategies for technopreneur authors to be considered to gain benefits from user generated content platform. Those factors are: characteristics for content, audience assessment, effectiveness of materials and profitable contents. In a nutshell, this paper exposes news tunnels; the most promising way that writers can express their talents in digital age as technopreneurs.
\end{abstract}

Keywords: Technopreneur, user generated platform, writer, digital age, industry version four, content

\section{Introduction}

The phenomenon of internet and information technology has transformed the way people do their activities. Today, people are no longer relying on traditional newspapers to get news contents. Instead, they access various internet services to get information. This is similar to other activities such as, the publication of traditional books that also experienced degradation as the growth of digital contents on the internet, for example on social media, user generated content platforms, blogs, and other internet portals.

According to the Encyclopedia Britannica (year 2007, page 415), publishing is "an activity that involves selection, preparation and distribution of written and visual materials." Examples of published materials are books, magazines and newspapers. The traditional view of publishing regards only printed materials as published materials. But, since "electronic books and online newspapers" are also reckoned to be types of publishing, the printed form is no longer a requirement for publishing (Encyclopedia Britannica, year 2007, page. 416). Traditional mediators such as books, magazines, brochures are no longer a public choice in obtaining information and are no longer an option for the industry to advertise its products.

The phenomenon of digitalization concerning the present society to get information also influences the choice of media that serves as a means of marketing. In Figure 1 it can be seen that marketing costs in 2014 representing various media changes every year such as in 2017 , traditional media like television, newspapers, magazines, advertisements in public spaces and even radio were degrading. On the contrary, information technology-based media had increased in 2017, such as desktop internet and mobile internet. 
Share of global adspend by medium (\%)
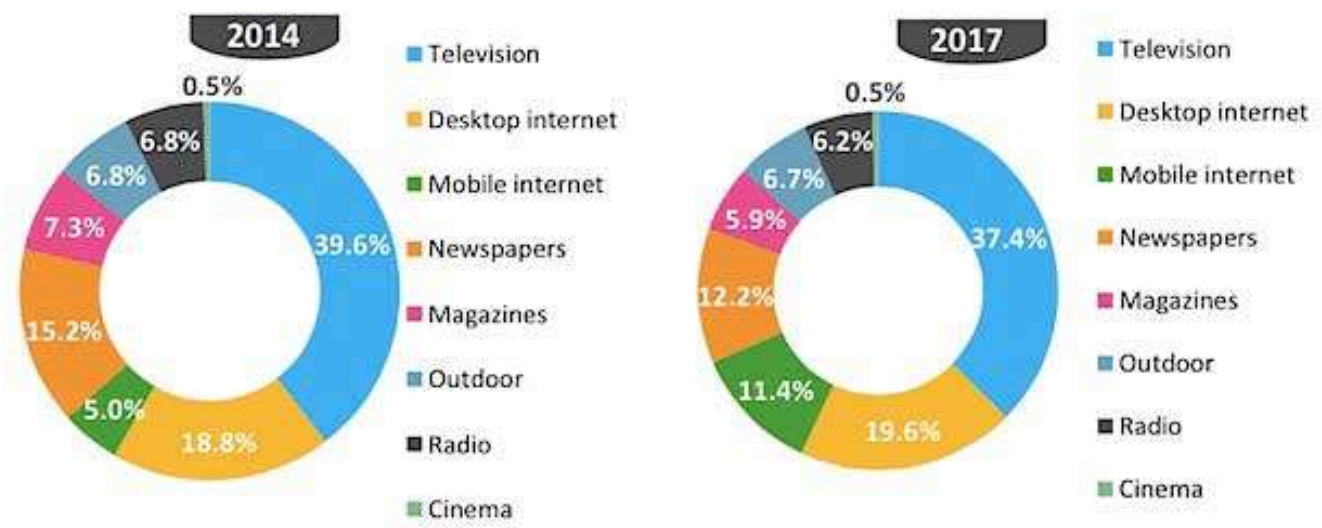

Source: Zenithoptimedia

Figure 1. (a) Ad revenue 2014; (b) Ad revenue 2017

This trend becomes an opportunity that must be addressed carefully by entrepreneurs who want to get opportunities in the information technology fields. In this case, for a technopreneur who is specifically engaged in content writing services, information technology becomes a platform in creating, especially in the use of papers that are gradually eliminated in digital technology based media. In the era of entrepreneurs, professional writers might be book writers, or authors who contribute to traditional magazines or newspapers. But today, the media has changed and technopreneurs actually open up new opportunities for professional writers.

Besides, a technopreneur who is engaged in the field of writing should be able to see trends in the interest and characteristics of readers. This is important in improving the visibility and view of the content he is writing. The result of this effort, in the entrepreneur's point of view, might be seen as business opportunities, income and profit.

\section{Literature Review}

Current information-based technologies are capable of transforming activities and sources of information that are sustainably evolving, which is called primarily web-based technology. Addressing the phenomenon above, the development of web technology version 3 to catalyze the exchange of information on the internet will become the next trend. Although the used of web technology is still based on web version 2, web version three is a concern in empowering the web in the future. If you look closely, web technology version three becomes the current digital content platform, although some media just use web version 2.

Regarding the different versions of web nowadays, the Wikipedia states: "Web 1.0 is Read Only, static data with simple markup for reading. Web 2.0 is Read/Write dynamic data through web services that customize websites and manage items. Web 3.0 is Read/Write/Execute." In Web 2.0, users not only read information from the internet, but also provide information through internet to share with others, in this case via systems and interchangeable data among intelligence systems.

Currently we have many popular Web 2.0 interactive applications like Blog, Mobile Blog, Podcast, Mashup, Tag, RSS/Atom, Wiki, P2P, AdSense, Distinctive Web portal, registered system and so on. Compared with Web 2.0, there is not a very clear definition available for Web 3.0 till now. Web 3.0 is a term used to describe the future of the World Wide Web. Views of different pioneers on the evolution of Web 3.0 might vary. The emerging technologies such as the Semantic Web will transform the way the Web is used, and lead to new possibilities in artificial intelligence based applications. The others have a notion that increases in internet connection speed, modular web applications and advances in computer graphics which will play the key role in the evolution of the new version of World Wide Web, that will appeared different that the previous WWW.

Some things that are differentiating web technology version three namely Web 3.0 is the third generation of web-based internet services. This means that the machine will have the ability to read the Web just as humans can do now. Web 3.0 deals with the concept of semantic Web, which enables web content to be enjoyed not only in the user's native language, but also in formats that can be accessed by software agents. Some experts even named Web 3.0 as the 
Semantic Web itself. The uniqueness of Web 3.0 is the concept by which humans can communicate with search engines. We can ask the Web to search for a specific data without bothering to search one by one on Web sites. Web 3.0 is also able to provide relevant information about the information we want to search, even without our request. Web 3.0 offers an efficient method of helping computers organize and draw conclusions from online data. Web 3.0 also enables Web features into a data storage facility with an enormous capacity.

Although still not fully realized, Web 3.0 already has some operational standards to be able to perform its function in accommodating metadata. If formulated, web 3.0 can be spelled out in the following formulation: WEB $3.0=4 \mathrm{C}+\mathrm{P}+$ VS $4 \mathrm{C}=$ content, commerce, community, context $\mathrm{P}=$ personality VS = virtual search

Thus, web 3.0 as a personal assistant knows everything about its users and can access the internet to find the answers needed.

Web 3.0 is a web where the concept of website or webpage is nothing more than just a media to exchange information, where data isn't owned but shared instead, where services show different views for the same web or the same data. This version has a significant contribution to enable writers to manage their content value from one system to another such as to spread the previous material to get wider audience.

\section{User Generated Content Characteristics}

User-generated content (UGC) is a new online media of content created by users of a system or service and is made publicly available on the system. UGC most often appears as a new way and a new feature for online platforms, such as social media sites, and may include content types such as blog posts, wikis, videos, comments, or e-commerce. These services have advantages regarding web version 2.0 and web version 3.0.

The term "user-generated content" and a concept that refers to incoming use of the mainstream in the mid-2000s, appears in web publishing and production circles of new media content. User-generated content is used for a variety of applications, including troubleshooting, news, entertainment, advertising, gossip and research. This is an example of the democratization of content production; whereas in the 1970s and 1980s, traditional "gatekeepers" such as newspaper editors, publishers and news events approved all content and information before being published in the 1990s and 2000s, as media production through new technology has become more accessible, user friendly and affordable to the general public, a large number of individuals can send texts, digital photos and digital video online, audio and many more.

Companies nowadays are beginning to see opportunities from the presence of User Generated Content in disseminating information and building a close community that can be managed internally. Utilization of User Generated Content is done by UC News, which is UC Web Content Distribution Platform that has 100 Million Monthly Active Users until April 2017. Following the launch of We-Media Reward Plan 2.0 program in mid-March 2017, the leader of user-based content ecosystem (user generated), UCWeb Inc.'s Alibaba Group announces the achievement of UC News applications until April 2017 that reaches 100 million monthly active users in Indonesia and India. First launched in August 2016, UC News has listed new achievements by becoming one of the fastest growing applications in the country with more than 20 million monthly active users in Indonesia in 7 months.

UC News is UCWeb's strategic product for content distribution. Donald Ru, General Manager of UCWeb Indonesia, Alibaba Mobile Business Group explains: "Starting last February, there were more than 1300 million article readers until April. This means we have 45 million readers of articles every day in Indonesia. Also, we see significant growth in average time spent by UC News users, who currently reached more than 20 minutes per person. The digitalization of this content completely changed the form of daily information acquisition in this fragmented reading era. "

As the consumption of digital content is growing, UCWeb wants to contribute more to the Indonesian content industry with the support of Big Data Artificial Intelligence technology as the main strength of this application. This technology can read customer's behavior, their preferences, Wi-Fi connection speed and other elements related to the reader's ability to access data, allowing each reader to get content tailored for them. AI technology can also predict topics that will often be discussed in the future and is UCWeb's secret to always be smart and follow the trend.

Content quality is an essential part of the reader, but UC News still sees low-quality content, such as hoax news, pirated results, duplication and content that violate norms that reduce the quality of reading. In the past, to filter content for readers requires a lot of manpower. However, it becomes impossible to process 250,000 articles daily on UC News. That's where Big Data and Artificial Intelligence technology is here to ensure a quality reading experience and also to work closely with our partners to regulate and to prevent the coming of low quality content and also to protect the quality content. 
Aiming to provide content distribution services and the experience of enjoying better content for partners and users, UC News launched We-Media Reward Plan 2.0 in mid-March. The program will select 1,000 independent publishers from Indonesia and India such as independent bloggers and writers simultaneously known as "We-Media", with a program called 'Super 1000' with a minimum income of 10 millions rupiahs every month for UC We-Media. It reflects UCWeb's commitment to creating opportunities for talented writers in Indonesia to have the ability to create a strong personal branding. UCWeb has set a new trend under UC We-Media program where everyone has the opportunity to create, write, share thoughts and interact with their readers at UC News.

UC News is a content distributor powered with big-data capabilities, being an integrated source for trendy news content and reaching out to all the popular categories that Indonesian people can enjoy anywhere, anytime. UC News brings various channels such as news, sports, technology, entertainment, lifestyle, health, humor, and so on. UCWeb's strength is a big data technology and AI to help UC News process millions of data requests as well as contents from multiple sources every day.

As a technology company, UC News seeks to build content distribution platforms that enable quality content, including PGC (Professionally Generated Content) and UGC (User Generated Content) to reach more users. We view the consumption of PGC and UGC content to actually grow together when the big-data distribution method of content is applied, which will also open the doors to more qualified content providers, both corporate and individual. Through this, we aim to provide content distribution services as well as a better content consumption experience for partners and readers.

UGC is a platform for gathering audience and building specific managed communities. Based on the model of intimacy below, it is explained that to reach the audience, the writer or contributor must create content that is capable of reaching the public area in this content that is often discussed by netizens. It is necessary for the foresight of contributors to create content that has high visibility opportunities in UGC. Contributors who only write for themselves and only write their preferred content will not effectively reach an audience to read it.

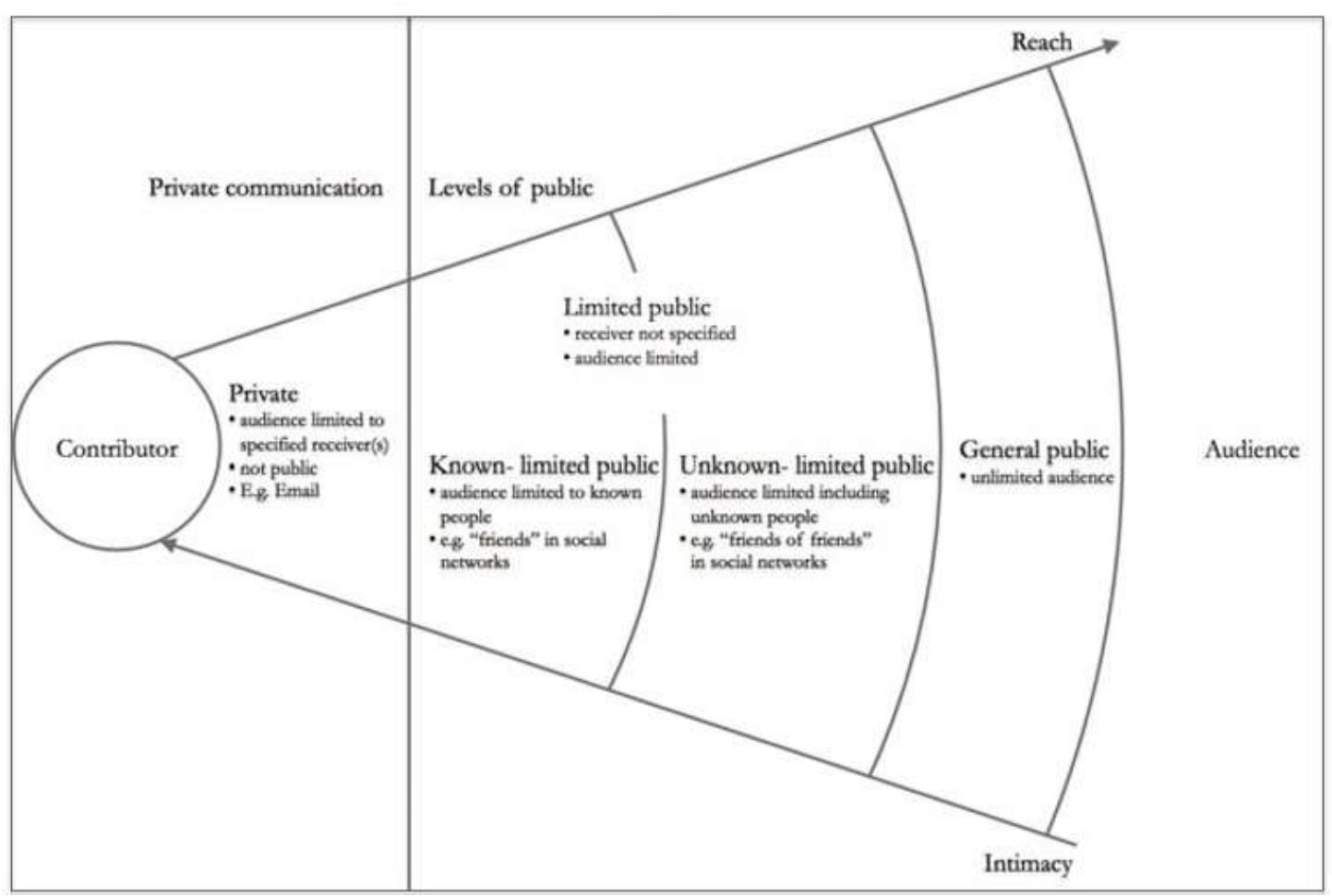

Figure 2. Reach Intimacy model in UGC

Reach-Intimacy-Model describes a personal and public-level communication for user-generated content related to reach intimacy. Personal communication is not considered to be user-generated content. User-generated content is a content published on the user's online platform. The term social media consists of platforms that contain user-generated content. 


\section{Technopreneur in User Generated Content}

Technopreneurship is as one of the concepts that is derived from "Entrepreneurship", which both have the principle of seeking profit as much as possible but more focused on a business that applies to a particular technology, not just replication of other business only.

In Drucker's view (1996) entrepreneurship is defined as an activity consistently performed to convert good ideas into profitable business activities. According to Suparno et al. (2008), entrepreneurship is the process of organizing and managing risks for a new business. An entrepreneur does the following: 1. Identify and evaluate market opportunities, 2. Find solutions to find those opportunities, 3. Gain needed resources (money, people, and equipment) in running a business, 4. Manage resources from start-up to survival and expansion, and 5. Manage the risks associated with the business.

Based on the above description, it can be seen that technology is part of the solution needed to meet the opportunities. Technology is only one of the five aspects of entrepreneurship required. Other tasks that an entrepreneur has to do are also very important. In this case technology is not everything in technopreneurship. However, IT-based technologies as enablers will identify the area of entrepreneurship, which is currently in the 4th industrial revolution.

\section{Industry version 4}

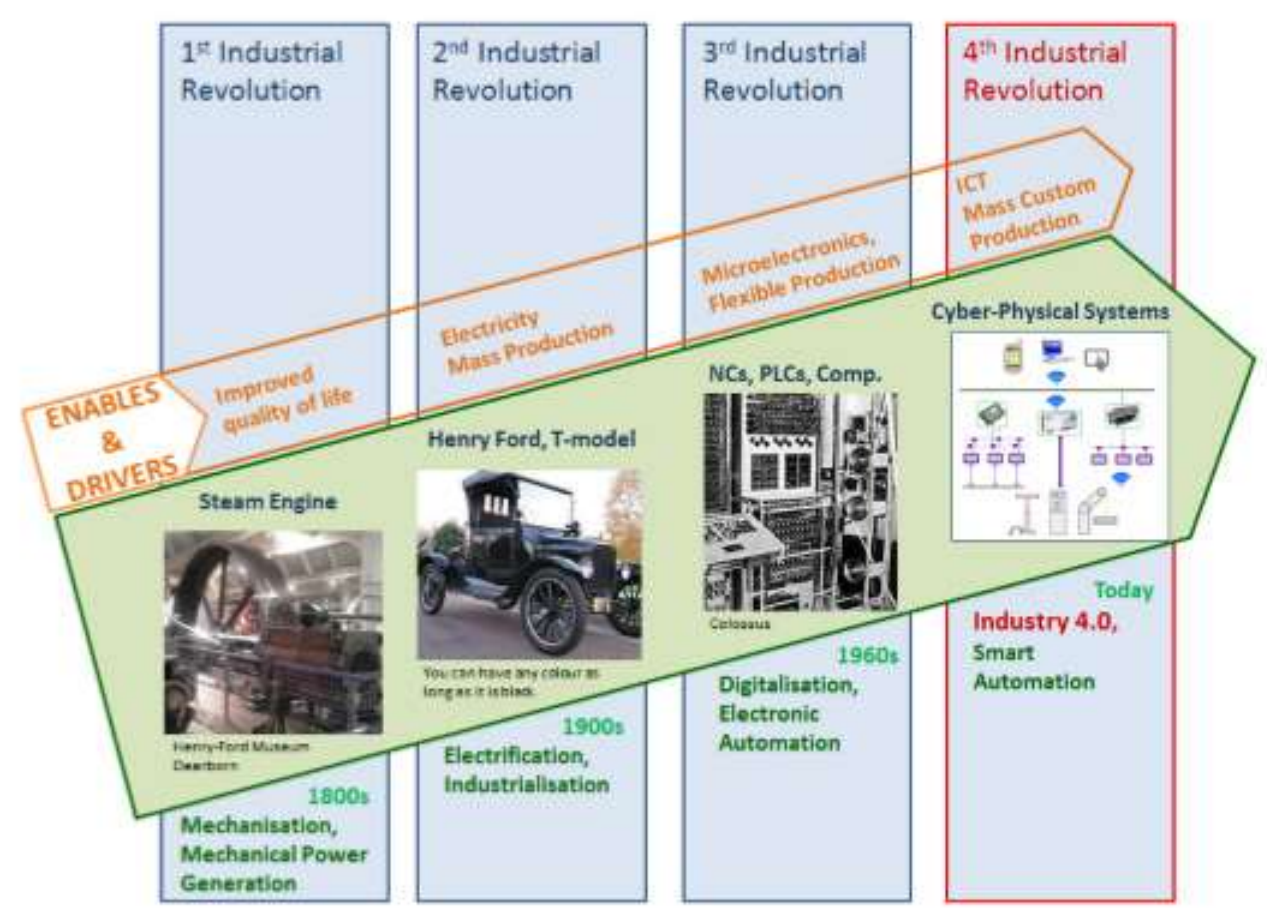

Figure 3. Industrial Revolution - Source: Industry 4.0 Concept: Background and Overview

Today we are in the fourth industrial revolution sparked by the development of Information and Communication Technology (ICT). The basis of technology is intelligent automation of cyber-physical systems with decentralized controls and advanced connectivity (IoT functionality). The consequence of this new technology for industrial production systems is the reorganization of classical hierarchical automation systems to self-organizing virtual physical production systems that enable flexible mass production and flexibility in production quantities.

In this regards, technology is a way or method to process something in order to occur cost and time efficiency, so as to produce a higher quality product. The basic foundations of the creation of technology are: the needs of the market, the solution to the problems of application of various fields of science, improving the effectiveness and efficiency of productivity, and modernization. Technopreneurship is a combination of the words Technology and Entrepreneurship which can be concluded as the process of formation and collaboration between business and application technology as a supporting instrument and as the basis of the business itself, both in the process, the systems of the parties involved, as well as the products produced.

In general, the word Technology is used to refer to the practical application of science to the industrial world or as a 
framework of knowledge used to create tools, to develop skills and to extract material to solve existing problems. The word entrepreneurship comes from and the word entrepreneur which refers to a person or agent who creates a business with courage to hold risks and uncertainty to recapture benefits and growth by identifying opportunities. A technopreneur is a person who runs technopreneurship or someone who runs a business that has the entrepreneurial spirit to market and utilize technology as a selling point. (Zimmerer and Scarborough, 2008; Luong, et.al 2017).

There is a difference between ordinary entrepreneurship and technopreneurship (technology entrepreneurship). Technology entrepreneurship must be successful on two main tasks, namely to ensure that the technology works according to the needs of the target customers, and that it can be sold with an ordinary profit. Generally, entrepreneurship only connects with the second part of selling by earning profit. Technopreneurship is not merely making products based on technology and selling the product. The understanding of this product is increasingly widespread with the integration of information technology tools that are used as a means with the goods and services done. Digital-based content becomes one of the domains that also empower existence of technopreneurs.

\section{Method and Assessment of UGC in Technopreneur Writer}

In this paper, the UCNews articles from certain accounts launch educational information technology. The outcome is not just getting feedback from audience, but furthermore to also gain income to the contributor. Some aspects will be seen when the content of this information technology education is launched through UGC. We will examine the impact of the content and the way it preserved. The results can be defined as a reference to strategy development, launching useful educational content, which is preferred by the audience and also a content that will increase visibility and contributor's income.

Several aspects which will be assessed from the UC News Dashboard are as follow:

- Today's Activities: Analyze audience's activities per day using a time series analysis to update every ten minutes, and in detail measure parameters: the number of users accessing the article, the increase in followers linked to the account that launched the article, and the detail view for each article.

- View History: Refers to the number of audience accessing articles and their characteristics categorized by: (1) View the UC News App -> This percentage comes from the large number of readers in the UC News app (2) View from Private Promotions -> This percentage comes from promotion through your social media. (3) View of Extra Benefits as a reputable creator.

- Ranking: This value indicator refers to how well an account launches an article, examined by the consistency of article creation, the influence of account status, level of activity and originality. The diagrams in the dashboard rank are shown in the form of a time-based chart.

- Income: Income is basically obtained as a form of appreciation from UGC providers to contributors. This Income can also be used as an economic feedback regarding the success of contributors to the community with the prescriptive writing made.

The dashboard showed the value of parameters based on quantitative approach provided by UCNews Dashboard (Ochoa \& Duval, 2008; Mahmud,Rahman \& Miah 2016) is the result of socio informatics activity, a phenomenon of how users interact with systems among users who use information systems that generate user-generated content (Mehmet, Erdins, 2005; Kling, 1999; Stoeckl, Rohrmeier, Hess, 2007). Larger scores are displayed on the dashboard then the article is made effective and targeted because in addition to being read by the audience, the article is created by audience for lectures and exchange meetings and is intended for every comment written by users for each article.

Based on the Reach-Intimacy-Model, articles that appeal to the audience will gain visibility and responsiveness from their auditions, it is very important to mobilize the community between technopreneur writers and their readers. 


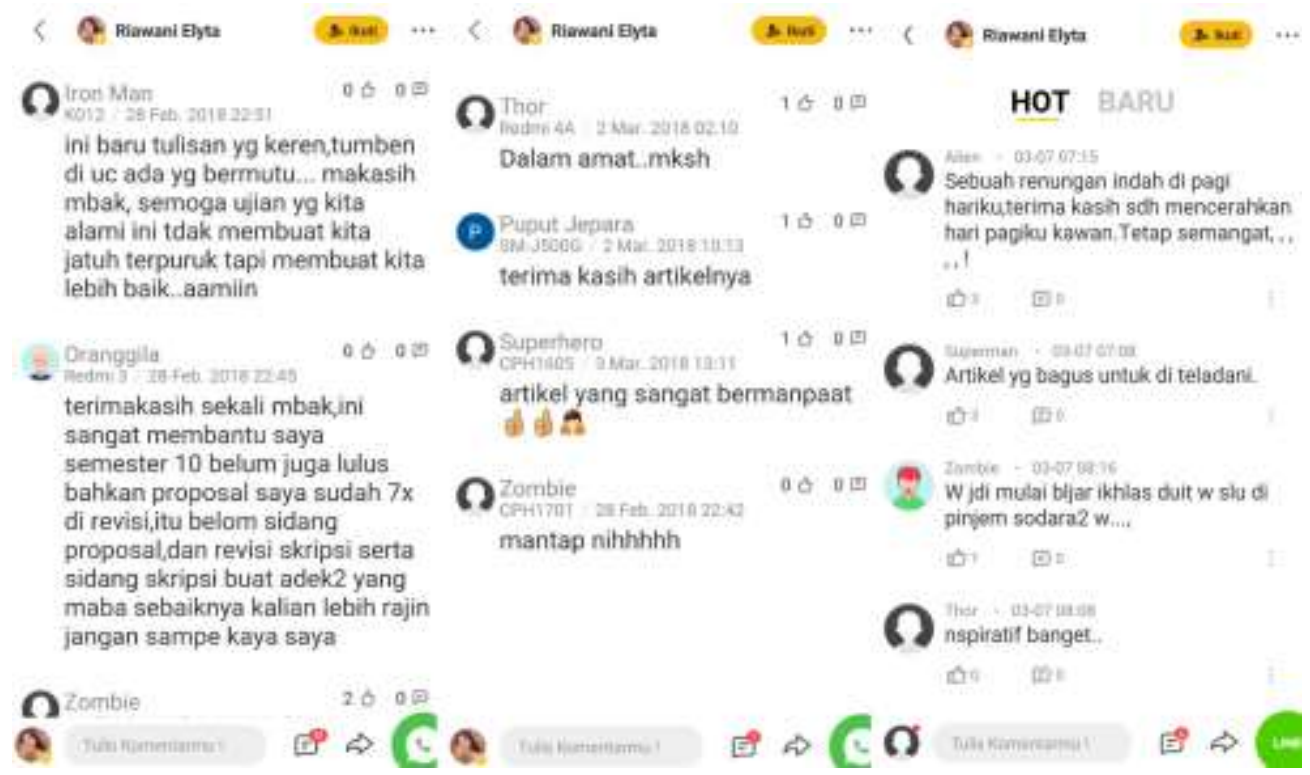

Figure 4. Audience's feedback regarding the article in UGC

There are guidelines for good content writing on UGC that are managed by UCNews. This includes the portion of content that is worth reading with a good quality, for example: word count, presence of images, videos, tags, and relevance to the author's profession.

Every UGC has its own rule book or guidelines. For example, some features on UCNews can be empowered to optimize the content writing for contributor, as described below:

1. Tool Bar: Various tools that are useful for writing your content. For example, use Italic on a foreign language or scientific term, use automatic numbering or bulleted lists when creating articles with bullet points. Use citation format when going to quote someone's words, etc. All of these tools have been designed to make writing formats tidier and easier for UC users to read.

2. Writing Competition and Related Topics: This will detect the article according to the theme recommendations and have more opportunities to recommend. You need to know that all the topics recommended on the page are the results of UC editor's analysis of UC reader data.

3. Categories and Tags: Tags will help the engine to easily detect your article type and pass it on to the right readers. You can only enter a maximum of 5 tags in 1 article.

4. Recommended Articles: The words written will appear like a preface when sharing articles on social media account, enhanced flexibility for distributing the articles.

Recommendation Strategy by UCNews System to improve visibility of effective content works well. It shows the success of the recommendation that reaches about $90 \%$, higher than $70 \%$. This unique phenomenon which includes how contents are published, user behaviors in reading the contents and how they participate and share their opinions are new in the way users are educated. It cannot be seen only in the perspective of social studies or information perspectives alone, so interdisciplinary or multi-disciplinary are not adequate as a bridge to assess these characteristics. Furthermore, trans-discipline has been built within the UCNews Portal system which is gradually making improvements and as users and authors contribute to user-made content platforms (Stock, Burton, 2011; .toeckl, Rohrmeier, 2007).

Here is an example of some of the UC News Portal User Generated Content dashboard features that can be viewed by contributors in creating content writing strategies, the best time to launch content, and as a means of audience feedback to published content. On the dashboard also listed the system assessment results on the performance of contributors. In addition, the dashboard also launches a variety of policies and updated information quoted by UC News portal for the contributors. 


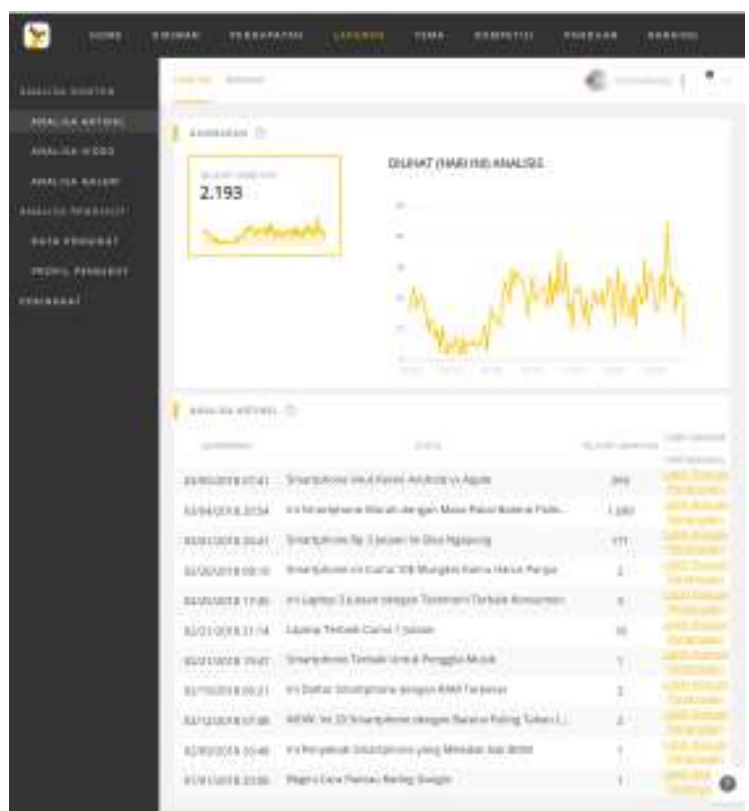

Figure 4. Example of UGC Dashboard for Contributors

In the observation of one of the UC News portal contributor accounts, there are 85 information technology articles reported by 4 to 5 articles every week. The review of these contributor accounts lasts from March 2017 to March 2018 , which gradually increases the number of followers against contributor accounts. The article was launched as an information technology article through themes, tags or keywords.

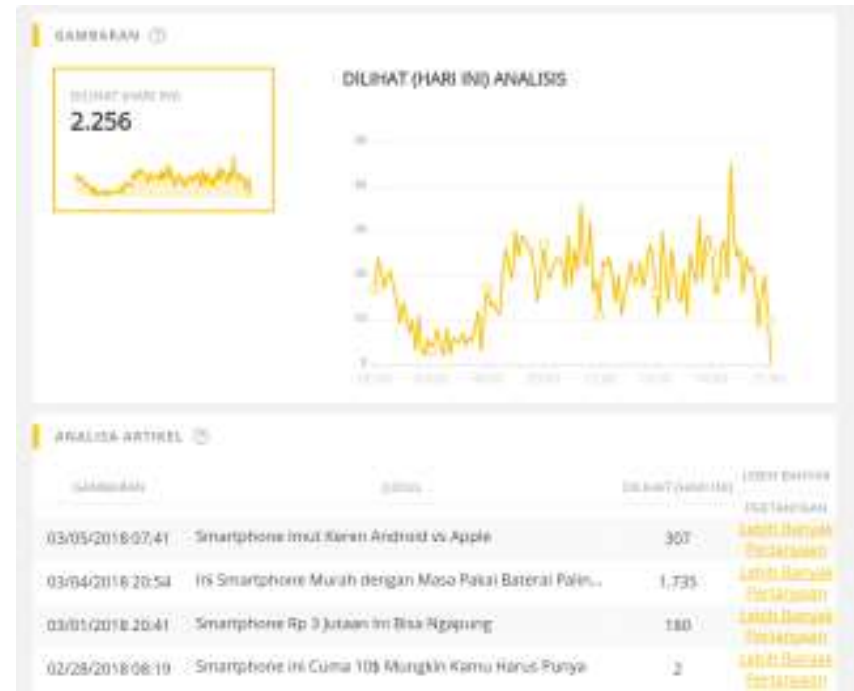

Figure 5. Monitoring audience activities based on 85 published articles offered

These measurements from dashboard known as Intelligent Perception Analysis are displayed on the dashboard showing the number of people viewing the content, the number of follower additions and time-based content activities. 


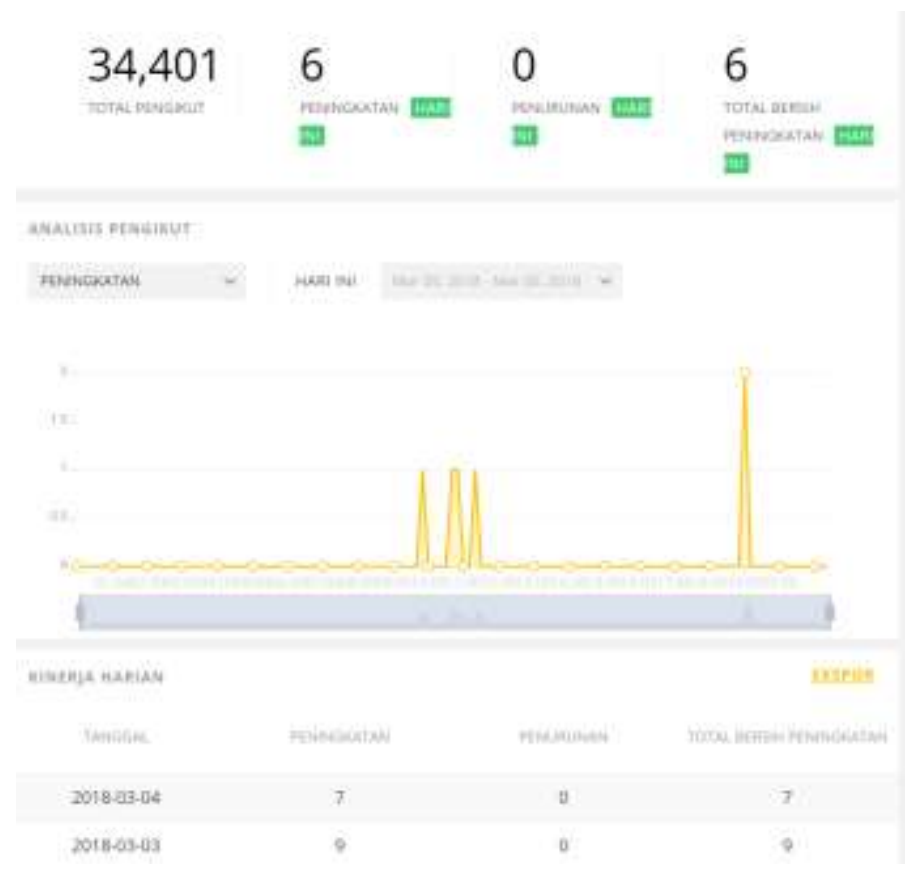

Figure 6. Information of the follower growth

Figure 6. shows that there is a growing number of followers, the activity of the number of people viewing the monitored content every 10 minutes. In UCNews' policies, accounts and articles, good quality will be maintained for maximum visibility, and 'sticky news' will be used so that articles can last longer in news feeds which is recommended by UCNews system for users to read.

The Ucnews dashboard provides details of follower growth. This growth identifies users who love content and want to get other similar news written by UCNews contributor accounts. Contents on UCNews are not only accessible through UCNews portal only, but can also be accessed by users outside the UCNews portal and the contents can be distributed on any system using links that have been created by the system so that more people can read them. Basically $90 \%$ of readers are audience on UCNews portal, others are derived from personal promotions through social networks, or on blogs, emails and various internet service portals that have links to those articles. 


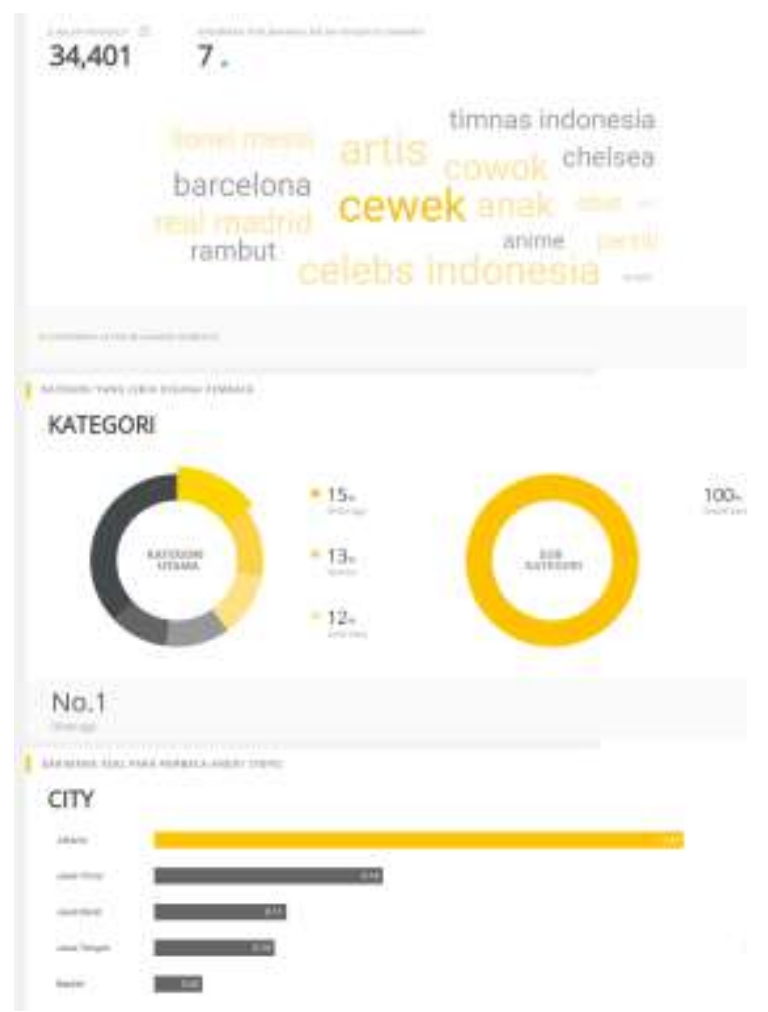

Figure 7. Information of the followers' and audience's characteristics

Based on the dashboard information provided by UGC UCNews, contributors analyze the most important trends and key words to improve audience rating. They also analyze the most contents that audience liked. For example, audience who liked sports content are about 15\%,13\% liked the humorous article, and 12\% liked the content which is fairly unique. And for sub category, which is sports, mostly audience like football contents. In mapping the audience, UC News portal divided the allocation of hearings into several areas of the city and region, for example: Jakarta, East Java, West Java, etc. Fig. 7.

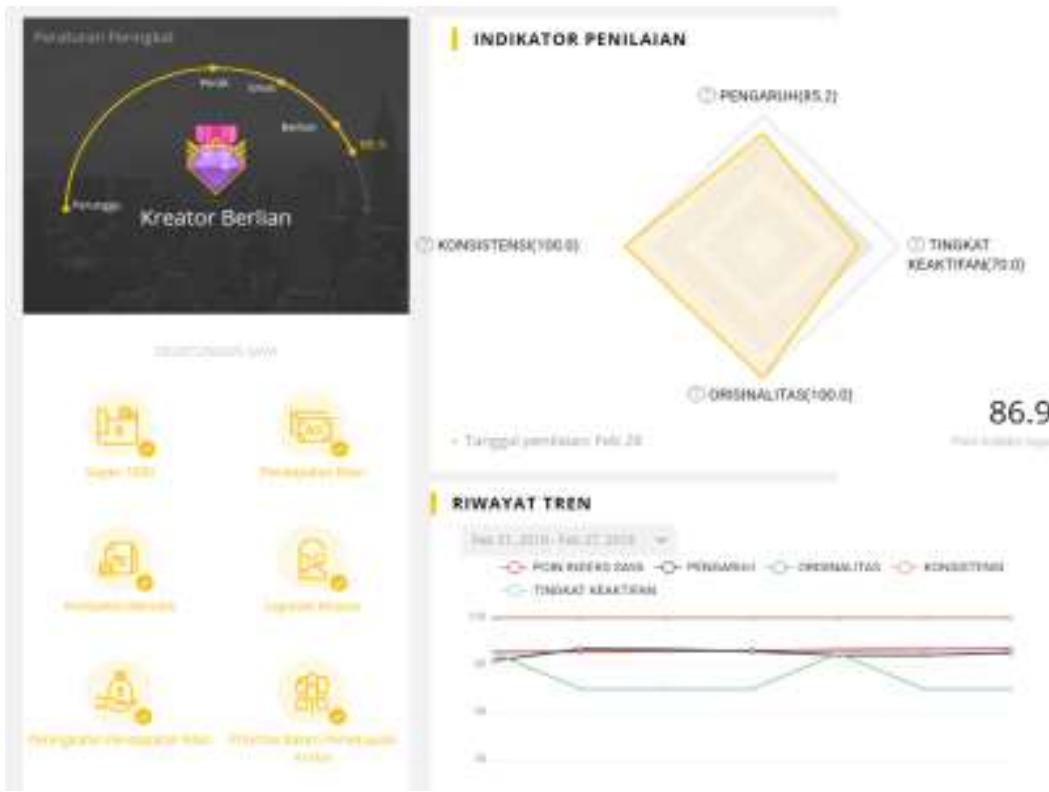

Figure 8. Rank Dashboard 
There are four factors that are used as parameters to assess the performance of contributors; the interface is named as 'a rank dashboard'. The four factors are: consistency, originality, level of activities of contributors and the influence of articles. In the example shown, the contributor has a score of 86.9. Based on UC News's assessment, contributors meet the society as qualified contributors.

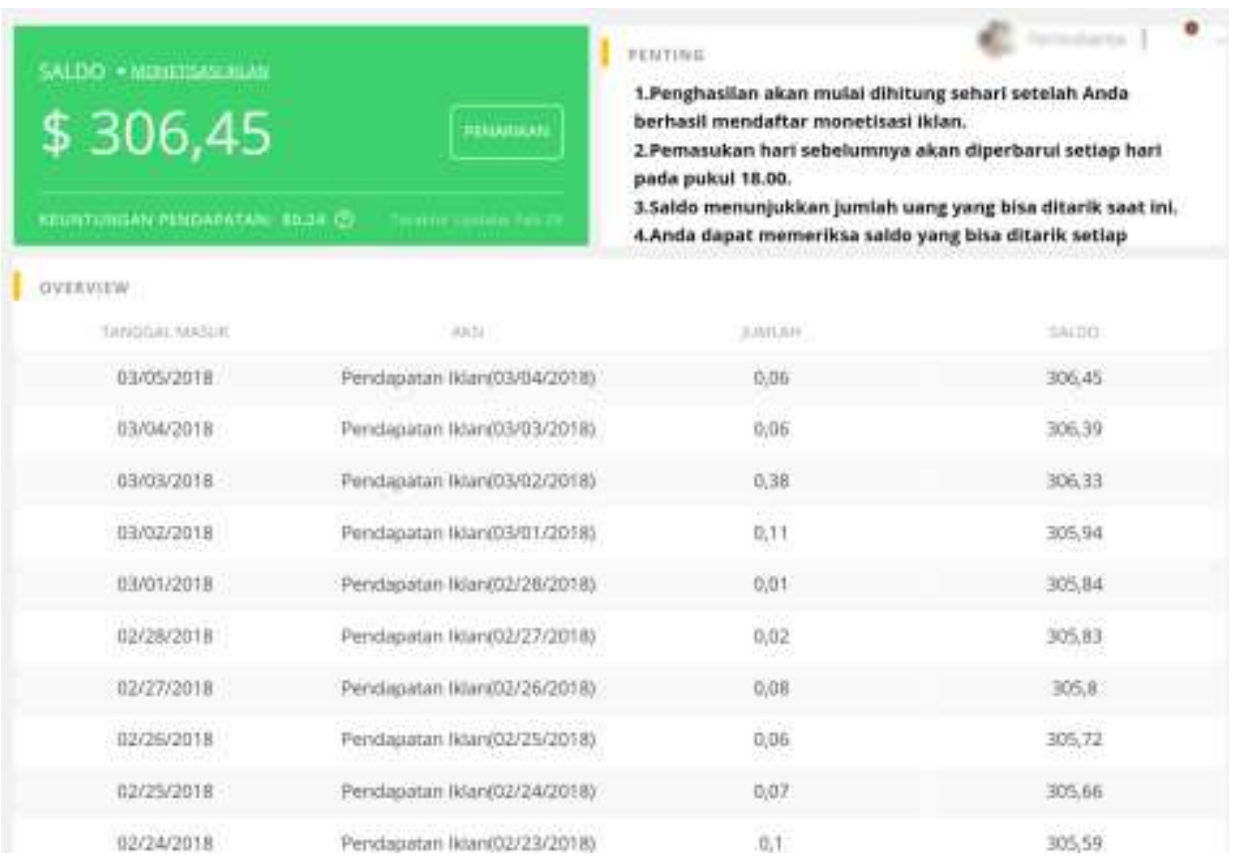

Figure 9. Income rate on a contributor's account

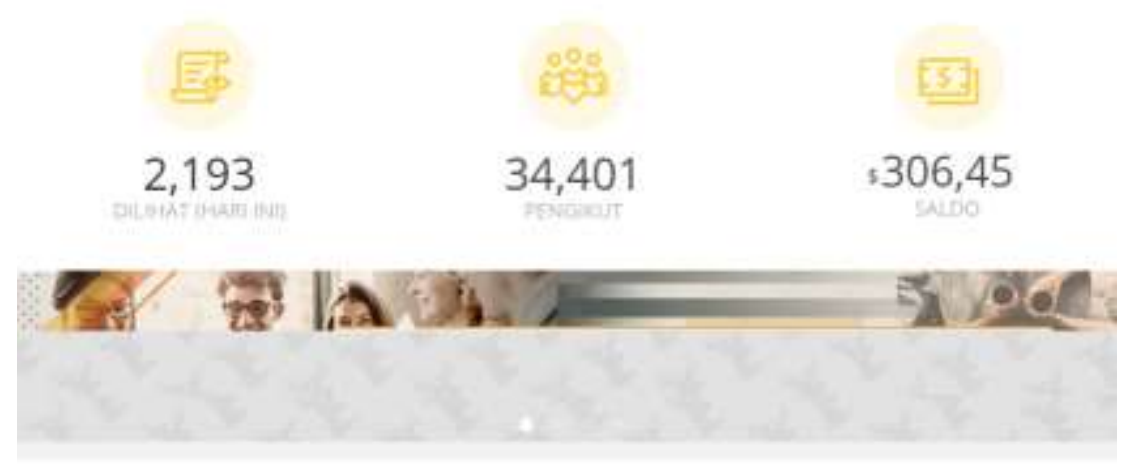

REXOMENDASI TEMA

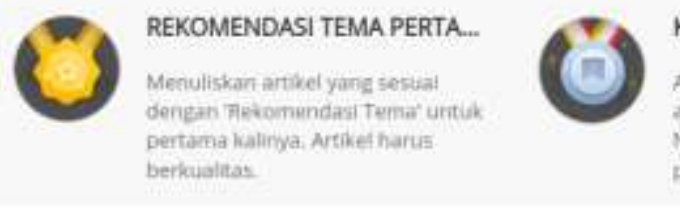

KEUNTUNGAN REKOMENDASI

Artwel beriwaitas sestial TEMA

skan diplih oleh tam editor UK:

News untuk direkomendaslkan

pauta karal katezori tertentu.

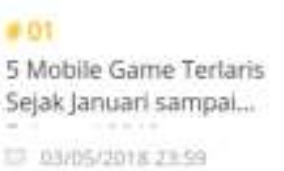

TULIS

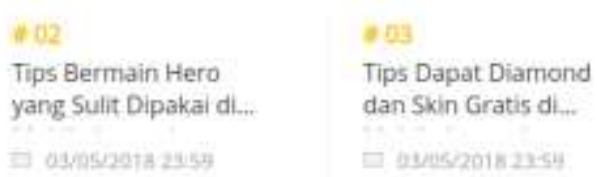

TULIS.

\section{Tuls}

Figure 10. Status, view, followers and income on a contributor's account 
One of successful technopreneur writers even gets a sizeable followers count of 250,000 followers and reaches 1 million views a day. And until now, the article of one of the contributors has been read by 29 million readers. Even with these conditions, being a technopreneur on UC News Platform produces salary that exceeds the salary of private employees.

In this research, doing the distribution of questioners at UGC Platform UC News becomes a means in cutting profession as tehcnopreneur writers. $80 \%$ replied that the result earned is equal to what has been done. Even $85 \%$ said that writing activity on UGC portal will open business opportunities and other cooperation offer for writers. And when asked if writing to UC News can be the main job, $40 \%$ agrees while the other $60 \%$ disagrees. There are also interesting things found from the opinions of the authors at UC News that $85 \%$ say that the writing profession on the portal will support Technopreneur Writers who have a profession as a writer.

\section{Conclusion}

The phenomenon of the development of digital technology in this case, we are already on web technology version 3 and in the era of industry version 4 , emerging trends and a number of technologies that can support the profession of writers in doing business as technopreneurs.

The user-generator content platform has benefits such as: business oriented advertising, capturing communities, launching valuable information and writing tools which have rich multimedia features, always accessible and active interaction between viewers makes this portal a prospective information tool. The UGC portal is an example of how modern society is educated, and is a way of getting good quality information content.

For a contributor, the feature on UGC allows them to manage content and create strategies for launching the work. As a writer or technopreneur writer, this phenomenon needs to be addressed carefully, so that an author can develop his business in portals like this, raise the audience, and make it known because of specific profession that they do through writing.

\section{Acknowledgements}

Feri Sulianta, started his career in 2001 as Chief Information Officer, currently active as a fulltime lecturer at Widyatama University and in several universities. The areas of interest are Information Technology, Socio Informatics and Social Studies. Currently Feri Sulianta is continuing his doctorate in Social Study at Indonesia University of Education.

Prof. Dr. H. Sapriya, M.Ed. Majoring: Education of Citizenship. Education: S-1 PMPKN, IKIP Bandung, 1987 S-2 Social Studies Education Latrobe University Melbourne - Australia, 1998. S-3 Education IPS, UPI, 2007

Tmt. Professor : April 1, 2010 Field of Science / Expertise: Civic education

\section{References}

C. Wyrwoll. (2014). User-Generated Content. Social Media, Springer Fachmedien Wiesbaden 2014. https://doi.org/10.1007/978-3-658-06984-1_2

Ceylan, M., \& Aslan, D. (2018). Cardinal Number Acquisition of Turkish Children. Journal of Education and e-Learning Research, 5(4), 217-224. https://doi.org/10.20448/journal.509.2018.54.217.224

Chang'ach, J. K. (2018). An historical trajectory of the economic transformation of the southern Keiyo community in Kenya. Global Journal of Social Sciences Studies, 4(2), 52-69. https://doi.org/10.20448/807.4.2.52.69

Dandan, M. M., \& Marques, A. P. (2017). Higher education leadership and gender gap in Jordan. Asian Development Policy Review, 5(3), 131-139. https://doi.org/10.18488/journal.107.2017.53.131.139

Digital Marketing Vs. Traditional Marketing - The Winners and Losers. https://jimmydata.com/blog/digital-marketing-vs-traditional-marketing-winners-losers/

Dincer, N., \& Kilinç, Z. (2018). The Analysis of Stress Levels of the Female Wrestlers Studying in Higher Education (A Case of Batman Province). Asian Journal of Education and Training, 4(3), 156-160. https://doi.org/10.20448/journal.522.2018.43.156.160

Dunst, C. J., Howse, R. B., Embler, D., \& Hamby, D. W. (2018). Evaluation of E-Learning Lessons for Strengthening Early Childhood Practitioner Use of Family Capacity-Building Practices. International Journal of Educational Technology and Learning, 4(1), 34-39. https://doi.org/10.20448/2003.41.34.39 
Luong, N. D., Long, H. V., Tuan, N. K., \& Thai, N. D. (2017). Properties of Concrete Containing Rubber Aggregate Derived From Discarded Tires. Asian Review of Environmental and Earth Sciences, 4(1), 12-19. https://doi.org/10.20448/journal.506.2017.41.12.19

Mahmud, M. A. R., Rahman, M. M., \& Miah, M. S. (2016). Performance Analysis of Routing Protocols for CBR Traffic in Mobile Ad-Hoc Networks. Journal of Information, 2(1), 1-9. https://doi.org/10.18488/journal.104/2016.2.1/104.1.1.9

Mbunda-Nekang, F. M. (2018). Preventing Conflict and Ensuring National Peace through Folklore: Option for Cameroon. International Journal of English Language and Literature Studies, 7(2), 22-31. https://doi.org/10.18488/journal.23.2018.72.22.31

Obi, M. N., \& Okekeokosisi, J. (2018). Extent of Implementation of National Entrepreneurship Curriculum in Tertiary Institutions as Perceived by Educators. American Journal of Education and Learning, 3(2), 108-115. https://doi.org/10.20448/804.3.2.108.115

Ochoa, Xavier and Duval, Erik. Quantitative analysis of user-generated content on the Web. (2008). pp. 19-26. In: Proceedings of the irst International Workshop on Understanding Web Evolution (WebEvolve2008), Beijing, China.

Okon, E. O., \& Richard, S. H. (2017). Gender and Transport Sector Employment: Evidence from Kogi State, Nigeria. American Journal of Education and Learning, 2(1), 1-13. https://doi.org/10.20448/804.2.1.1.13

Önder, M. (2018). Contribution of Plays and Toys to Children's Value Education. Asian Journal of Education and Training, 4(2), 146-149. https://doi.org/10.20448/journal.522.2018.42.146.149

Ozkurt, B., \& Alpay, C. B. (2018). Investigation of Proactive Personality Characteristics of the Students of High School of Physical Education and Sports through Various Variables. Asian Journal of Education and Training, 4(2), 150-155. https://doi.org/10.20448/journal.522.2018.42.150.155

Özmaden, M., Soter, F., \& Özmaden, H. (2018). The Physical Education and Sport Studies in the Framework of Social Demands-Institutional Structuring and Teacher Training the Developments before and during Turkey Training Community Alliance Period (1922-1936). Asian Journal of Education and Training, 4(3), 170-175. https://doi.org/10.20448/journal.522.2018.43.170.175

Phoutthaphone, S., Dahuai, Y., \& Jing, W. (2017). Application of Marxist Philosophy in Higher Educational Institutions in Lao PDR. International Journal of Asian Social Science, 7(8), 674-683. https://doi.org/10.18488/journal.1.2017.78.674.683

Puteri, L. H. (2018). The Apperception Approach for Stimulating Student Learning Motivation. International Journal of Education, Training and Learning, 2(1), 7-12. https://doi.org/10.33094/6.2017.2018.21.7.12

R. Kling, What Is Social Informatics and Why Does It Matter? (1999) D-Lib Magazine, Volume 5, Number 1, ISSN 1082-9873. https://doi.org/10.1045/january99-kling

Riyanti, M. T. (2018). Development of Learning Devices Commercial Graphic Based Planning Project. International Journal of Education, Training and Learning, 2(1), 1-6. https://doi.org/10.33094/6.2017.2018.21.1.6

Rusok, N. H. M., Kumar, N., \& Ab Rahman, S. M. (2017). A Contemporary Approach to Entrepreneurship Education and Training. International Journal of Asian Social Science, 7(8), 696-707. https://doi.org/10.18488/journal.1.2017.78.696.707

Saeed, N., \& Kayani, A. I. (2018). Role of College Principals in Promoting Quality of Education in District Kotli AJ\&K. Asian Journal of Contemporary Education, 2(2), 149-158. https://doi.org/10.18488/journal.137.2018.22.149.158

Salim, M. N., \& Hariandja, N. M. (2018). Factors affecting joint stock price index (CSPI) and the impact of foreign capital investment (PMA) Period 2009 to 2016. Humanities and Social Sciences Letters, 6(3), 93-105. https://doi.org/10.18488/journal.73.2018.63.93.105

Sandy, W. (2018). Factors Influencing Indonesian Students Satisfaction During their Studies in China. Asian Journal of Contemporary Education, 2(2), 136-148. https://doi.org/10.18488/journal.137.2018.22.136.148

Sawyer, Steve. Tyworth, Michael. (2006). Social Informatics: Principles, Theory, and Practice. Social Informatics: An Information Society for all? Proceedings of the 7th International Conference 'Human Choice and Computers', IFIP-TC9 'Relationship between Computers and Society', Springer: London, pp. 49-6. 
https://doi.org/10.1007/978-0-387-37876-3_4

Sudaryana, B. (2018). The Development of Smart House Model in Garut; The Advancement of Non-Formal Education Program. Asian Journal of Contemporary Education, 2(2), 84-89. https://doi.org/10.18488/journal.137.2018.22.84.89

Sulianta, Feri. Zainul,Asmawi. User Generated Content As A Platform To Develop State Of The Art Creative Learning Strategy. National Seminar on Social Studies and History Education (ISSSHE 2017). Universitas Pendidikan Indonesia. 2017.

Tang, Y., \& Khan, M. B. U. (2018). Internal Law Enforcement Challenges in Bangladesh: An Analysis. Humanities and Social Sciences Letters, 6(3), 106-120. https://doi.org/10.18488/journal.73.2018.63.106.120

UC News, Platform Distribusi Konten. UC Web Catat 100 Juta Pengguna Aktif Bulanan Hingga April 2017. https://wm.ucweb.com/notice_detail.html?id=ec85ddae9b6c44d3959c176de325bc9e

Wang, K., \& Yang, Z. (2018). The Research on Teaching of Mathematical Understanding in China. American Journal of Education and Learning, 3(2), 93-99. https://doi.org/10.20448/804.3.2.93.99

Yaraghi, E., \& Shafiee, S. (2018). Roles of Learner Autonomy and Willingness to Communicate in Communication Strategy Use of EFL Learners. International Journal of English Language and Literature Studies, 7(3), 55-74. https://doi.org/10.18488/journal.23.2018.73.55.74

Yazdanjoo, S., \& Fallahpour, H. (2018). A Study on the Correlation between Creative Thinking of Iranian EFL Learners and Using Metaphor in Descriptive Writing Tasks. International Journal of English Language and Literature Studies, 7(2), 32-44. https://doi.org/10.18488/journal.23.2018.72.32.44

Yildirim, S. (2018). The Effect of Educational Videos Used in History Education on Academic Success. Journal of Education and e-Learning Research, 5(3), 193-207. https://doi.org/10.20448/journal.509.2018.53.193.207

Zhang, W. B. (2018). Endogenous Economic Growth with Education Subsidies. International Journal of Emerging Trends in Social Sciences, 2(1), 10-16. https://doi.org/10.20448/2001.21.10.16

Zheng, J. (2018). The Incorporation of Subject Knowledge in Teaching Scientific Translation. International Journal of English Language and Literature Studies, 7(2), 45-49. https://doi.org/10.18488/journal.23.2018.72.45.49 